\title{
'COMING HOME FROM WORK ALONG GREY RED ARMY STREET': THE USE OF COLOUR IN POLISH LITERATURE AFTER 1945
}

\author{
KatARZyna ZeChenter \\ University College London, School of Slavonic and East European Studies
}

MY examination of colours in post-war Polish literature divides the literature into four phases between 1948 and the I990s. The first phase is that of Socialist Realism (I948-56), when the easily visibly propagandistic element affected all aspects of a literary work, including its use of colours. The second phase is the post-I956 years, when propaganda played a lesser role and when colour was used in a realistic manner, in contrast to the preceding period. The third phase covers the period I976-89, the poetry of the Nowa Fala (New Wave), and the poetry written during the period of martial law that concerned itself extensively with the social and political problems of the day. These were the years when colour again become closely associated with the mood of the society and the ethical attitudes of the writer. The final section refers to the use of colour in the literature of the phase between I 989 and 2000, when the sheer range and intensity of colour symbolism became closely connected with freedom, both political and individual.

\section{The Politicization of Colour in Socialist Realism (1945-56)}

Polish literature in the period immediately following the Second World War reflected the major dilemmas not only of writers but also of the ordinary citizen. The Poles, exhausted and pessimistic after the war, generally despised the Communist system and yet usually collaborated with it. ${ }^{\text {I }}$ For many who came from poor, backward villages, the new system offered hope because of rapid industrialization and the jobs open to them in places such as Nowa Huta, the newly-built industrial suburb of Cracow. ${ }^{2}$ Although the immediate post-war years did not witness such aggressive propaganda as the early I950s, literature became one of the major instruments used to promote the new system.

I Krystyna Kersten, Między wyzwoleniem a zniewoleniem: Polska 1944-1956, London, I993, pp. 5-27.

2 [Anon] Nowa Huta - duma narodu, Cracow, I952. 
The limited freedom of speech that existed immediately after the war began to disappear around I948, and the period of transition ended when the terror began. ${ }^{3}$ In January I949, the Szczecin Conference of the Union of Polish Writers adopted Socialist Realism. From then on all literary production had to reflect the class struggle and the leading roles of the Soviet Union and the Communist Party, even in its use of colour. The aesthetic value of any literary work was perceived to lie in its optimistic message because 'pessimism is a major feature of bourgeois culture', while optimism 'is in its essence revolutionary'. ${ }^{4}$ Consequently, colours in the literature of Socialist Realism were subordinate to ideology. The employment of light colours suggested general optimism, while darker tones were reserved for the past, ignorance (ciemnota) and 'enemies of the people'. The use of red emphasized the victory of the Red Army over Germany and linked that victory to Socialism. A typical example of the way colour was used can be found in a I95 I newspaper article on the reconstruction of Warsaw, in which Lesław M. Bartelski emphasizes the freshness and cleanness of the new Warsaw through the red roofs of the new buildings and 'the light colours of their façades' (blue, pink, white and cream). ${ }^{5}$ It was as if the past were now cleansed and its ills made good.

If, however, a reader were to look at pictures of the reconstructed, colourful houses as published in the press of the time, those pictures would be in black and white only and almost always out of focus. Even Przekrój (Cross-section), for some time the only illustrated weekly in post-I945 Poland, gave only a dirty pinkish background to the pictures of the buildings; this was the limit of the availability of colour in the press in the immediate post-war years. ${ }^{6}$ The happy colours of the reconstructed Warsaw and other cities were left to the readers' imaginations.

At the height of Socialist Realism, the use of colours was simplistic and dependent on the message of the work. Most novels focused on a few major themes such as new construction sites, factories and coalmines. Consider the construction sites in Przy budowie (At the construction site, I95I) by Tadeusz Konwicki (born I926) or Jesteśmy z Nowej Huty (We are from Nowa Huta, I95I) by Janina Dziarnowska (1903-I992). New factories provide the setting in Madre zioła (Smart herbs, I95I) by Wojciech Żukrowski (I9I6-2000), Penicylina (Penicilin, I95I) by Aleksander Jackiewicz, and in Władysław Żesławski’s Mirków ruszył (Mirków started working, I950). Coalmines are the focus of Wegiel (Coal, I950) by Aleksander Ścibor-Rylski (I928-I983).

A novel by Jan Wilczek about a food factory, Numer 16 produkuje (Number I 6 is producing, I95I), offers a key example of the way colour was employed in Socialist Realist novels. Light (including the open air) suggests positive things, while dark is connected either with the past or with negative aspects of the immediate post-war period such as the scarcity of commodities or the housing shortage. Thus, the walls of the factory, although badly damaged, are 'sparkling white', ${ }^{7}$ suggesting optimism since the factory is beginning to produce despite its poor state of repair. In a newspaper, however, the 'bold, black letters' of a headline announce the actions

3 Krystyna Kersten, 'The Terror, I949-I954', in A. Kemp-Welch (ed. and trans.), Stalinism in Poland, 1944-1956. Selected Papers from the Fifth World Congress of Central and East European Studies, Warsaw, I995; Basingstoke, I999, pp. 78-94.

4 Stefan Żółkiewski, ‘O literaturze współczesnej’, Kuźnica, 37, I947, p. 5.

5 Lesław M. Bartelski, 'Gwiazdozbiór Mariensztatu', in Kazimierz Koźniewski (ed.), Most, Warsaw, I95 I, pp. $42-43$.

${ }^{6}$ Przekrój, October I2-I 8 I947, pp. 4-5.

7 Jan Wilczek, Numer 16 produkuje, Warsaw, I95I, p. I22. 
of anti-Communist guerrilla units, thus connecting darkness with crime: 'The activity of forest gangs, spilt blood of worker-activists - sabotage. ${ }^{8}$

Other colours used by Wilczek include red and green. A visit to the Red Army cemetery, protected by a red fence, reminds the protagonist of the many Soviets who gave their lives fighting for the new socialist Poland. In other words, the use of red reinforces the connexion between Poland's liberation and the Red Army. Soviet soldiers are presented through the imagery of soil and the steppes to suggest historical and, more important, natural inevitability. The Red Army becomes an intrinsic part of historical justice and thus its presence in Poland needs no further justification: 'Russians were brown like the steppes - and simple. They came after the green SS-men [...] like a high tide. They washed the others away like a flood.'9

Propaganda literature of the period is an extreme case of the use of colour to support a novel's message because its theme is simplified for the naive reader. Kazimierz Koźniewski's novella Biała plebania $w$ Wolbromiu (A white parsonage in Wolbrom, I95I) was part of a campaign against the Catholic Church in Poland and, in particular, against Czesław Kaczmarek (I895-I963), Bishop of Kielce, who had been accused of collaboration with the Germans. ${ }^{\text {IO }}$ The novella is based on the contrast between the white walls of the parsonage with its traditional symbolism of purity and its 'true' activities, that is, the work is overtly employing the biblical imagery of the whited sepulchre:

\begin{abstract}
The parsonage in the city of Wolbrom is white and pretty. Situated on a hill near the market square, it seems to dominate the whole city. This topographic symbol highlights the ethical duties that the inhabitants of the house have towards the inhabitants of the city: the priest should lead them towards spiritual matters, direct their moral actions, demonstrate the qualities of truth and virtue. Is this what the people hear in the white parsonage in Wolbrom? ${ }^{\text {II }}$
\end{abstract}

Koźniewski presents priests as supporters of murderers despite their awareness that 'white is white and black is black'. ${ }^{\text {I2 }}$ For the unsophisticated readership the narrator repeats the straightforward contradiction between murderous religious leaders and the white walls of the presbytery within which they live several times, thereby reducing to a simple formula the conflict between the Communist Party and its political opposition: the clergy (and thus the Church) is corrupt while the Communists are pure.

Among the few basic colours used by the literature of the period, red has a special status, and is associated with the values that the Communist Party was promoting. Red (czerwony) is the only colour associated with Communism, not scarlet or crimson. The Polish words purpura (crimson, purple), szkarłat (scarlet) and especially karmazyn (crimson), which used to connote the Polish nobility of ancient lineage, and so entitled to wear crimson dress, are not used in connexion with Communism precisely because of their association with the upper classes or the clergy.

\footnotetext{
${ }^{8}$ Ibid., p. I92.

9 Ibid., p. 88. of Thaw following the death of Stalin.

II Kazimierz Koźniewski, Biała plebania $w$ Wolbromiu, Warsaw, I95 I, p. 40.

I2 Ibid., p. I2.
}

Io Czesław Kaczmarek, bishop of Kielce, was arrested in I95 I. After being submitted to severe torture, sleep deprivation and interrogation that lasted up to forty hours at a stretch, he broke down and confessed to whatever the Secret Service demanded: collaboration with the Germans, trying to overturn the Polish government and participation in the political underground. He was rehabilitated in I956, during the period 
In contrast, the word czerwony links the colour with blood and the struggle for justice and, important, with Socialism, and it already had reputable antecedents. Czerwony sztandar (The red banner), a revolutionary song by Bolesław Czerwieński (I85I-I88I), was written in I $88 \mathrm{I}$ and become an unofficial anthem of the early Polish socialists: it was sung during political demonstrations and by political prisoners before their execution. ${ }^{13}$ In that song, Czerwieński contrasts the red banner stained with the blood of the workers to the crumbling 'old world' and professes that a 'new order' is coming. Thanks to the song's role in post-I945 propaganda, the popularity of Czerwony sztandar and the association between blood and red was assured. Even later, in the late I970s, this association was strong enough for Stanisław Barańczak to quote ironically from Czerwieński's song in a poem, 'W zasadzie niemożliwe' (In principle, this is impossible, I977), when he refers to the colour of Poland during official state celebrations. ${ }^{\mathrm{I}}$

The literature of the I950s employed the colour red in the context used by Czerwieński because it refers back to the price paid by Marxists and because it indirectly accords legitimacy to the post-I945 regime. Moreover, the blood spilt in post-I945 Poland sanctifies the struggle for Communism as it sanctified the banner in Czerwieński's poem. The image of spilt blood becomes a cliché in the I950s, but it was present in a vast number of poems about the war and the immediate post-war years, for example in one poem by Andrzej Braun where a man dies 'with the red-blood star of Communism on his lips'. ${ }^{\text {Is }}$

Many novels of the period use the word 'red' in their titles as an explicit sign of their authors' ideological commitment. Let us consider three examples: first, in I95 I Tadeusz Borowski, an author of realistic stories about German concentration camps, published a collection of short stories entitled Czerwony maj. Opowiadania (Red May. Short stories) glorifying the Communist struggle. In one of these stories, Kłopoty pani Doroty (The troubles of Mme Dorota), Borowski venerates the activity of the Security Service and its methods, for example the execution of people for offences such as black-marketeering. ${ }^{16}$

Second, any attempt in the past to improve the lot of the workers or peasants could be now presented as an early Communist idea, as is suggested in the popular novel by Henryk Syska, Czerwony kasztelanic. Opowieść o Edwardzie Dembowskim (Red governor. The tale of Edward Dembowski, I95I), which is devoted to a nineteenth-century revolutionary of noble origin who was killed in the Cracow uprising of I 848 .

Third, all social strife of the past is presented as a struggle between right and wrong, in which the enemy is an agent of 'capitalists and the bourgeoisie'. Doing physical harm to the class enemy is right, because he is in a state of suspended humanity. In Monika Warneńska's (born I922) Czerwona kokarda (Red cockade, I950), a collection of schematic short stories about pre-war Poland, starving coalminers badly beat up a policeman. ${ }^{17}$ In this context, the violence symbolizes historical justice since in socialism, as Mircea Eliade notes, individuals become transformed into types, archetypes or roles; they represent the evil of a system and

${ }^{13}$ Józefa Bartnicka, 'Czerwony sztandar', in Literatura polska. Przewodnik encyklopedyczny, 2 vols, Warsaw, I984, I, p. I65.

${ }^{14}$ Stanisław Barańczak, 159 wierszy 1968-1988, Cracow, I990, p. 49.

is Andrzej Braun, 'Atak Pierwszego Batalionu', in Bohdan Urbankowski, Czerwona msza czyli uśmiech Stalina, 2 vols, Warsaw, I998, I, p. 293.

${ }^{16}$ Michał Głowiński, Rytuat $i$ demagogia. Trzynaście szkiców o literaturze zdegradowanej, Warsaw, I992, pp. $46-55$.

${ }^{17}$ Monika Warneńska, Czerwona kokarda, Warsaw, I950, p. I34. 
not individual human beings ${ }^{\mathrm{I}}{ }^{\text {' }}$ good people', the poor and starving coalminers in Warneńska's story, represent the driving force of historical progress.

The popularity of red is especially visible in verse, partly because of its role in propaganda: poetry was published in almost every newspaper and journal of the period. As early as during the Soviet occupation of the eastern part of Poland (I939-4I) some poets glorified the Soviet Union and its secret police: Leon Pasternak (I9I0-69), Ignacy Fik (I9IO-42), Józef Nacht-Prutkowski (I9I5-8I) and Arnold Słucki (I920-72) are almost entirely forgotten today; they used red as a metaphor for Communism in the spirit of Czerwieński's poem. The Communist is, to use Ignacy Fik's words 'a red ray of the sun', ${ }^{19}$ an image where the symbolism of light fuses with the Communist red. Employing the colour red as a synonym for righteousness and devotion became almost obligatory in the schematic poetics of Socialist Realism. In Julian Tuwim's (I 894-I953) poem devoted to Jerzy Borejsza (I905-52), a politician and editor, love for the leader is expressed by the red of flags which are 'more red and more beautiful / in their past and future glory / than all the red roses / that I could not place / on the coffin of the Communist, Jerzy Borejsza'. ${ }^{20}$ In Konstanty Ildefons Gałczyński's (I905-53) 'Poemat dla zdrajcy' (A poem for a traitor, I95I) the whole of life, permeated as it is by Communism, is encapsulated in 'the red flag of our days' ${ }^{21}$ It is not surprising, then, that Bohdan Urbankowski entitled his passionate account of the sovietization of Poland Czerwona msza albo uśmiech Stalina (The red mass, or The smile of Stalin, I995).

From the propaganda viewpoint by far the most important is the opposition between the darkness of the past and the light associated with socialism. In Tadeusz Konwicki's words: 'we don't want to live half a day in a daylight, and the rest in darkness'; ${ }^{22}$ darkness here suggests that there is a place, of some danger, that lies beyond the safe circle of the collective and the Party and provides a space where political error can assert itself. There was some extra merit in this opposition because it could convey a link to Lenin's statement that 'Communism equals Soviet power plus the electrification of the entire country'. The opposition of light and darkness permeates the majority of poems written at the time. Andrzej Mandalian's (born I926) longish poem 'Towarzyszom z Bezpieczeństwa' (To the comrades in the Security Service, I953) glorifies the interrogation methods of the officers of the Security Service, portraying the struggle with the enemy within, who lurks in 'dark corners' of the country. ${ }^{23}$ Even if the workers have to live six to a room while engaged in the construction of Nowa Huta, as described in a collection of enthusiastic journalistic pieces, Nowa Huta, the emphasis lies on the light that enters the rooms. ${ }^{24}$ According to Arnold Słucki, the author of the volume Stonce, nasz towarzysz (The Sun, our comrade, I95I), light is necessary to see both friend and foe. Its source is precisely defined as coming from the Kremlin, the undisputed centre of the universe in Socialist Realism. Słucki writes in a poem 'Chorągiew światła' (The banner of light, I95I):

I8 Mircea Eliade, Religia, literatura i komunizm. Dziennik emigranta, trans. by Adam Zagajewski, London, I990, p. 224.

I9 Ignacy Fik, 'Armia wyzwolicielka', in Bohdan Urbankowski, Czerwona msza czyli uśmiech Stalina, 2 vols, Warsaw, I998, I, p. 243.

${ }^{20}$ Julian Tuwim, Wiosny i jesienie. Wiersze dawne i nowe, Warsaw, I954, pp. 207-08.

${ }_{21}^{21}$ Konstanty Ildefons Gałczyński, Poezje, Warsaw, I976, p. 355.

22 Tadeusz Konwicki, Godzina smutku, Warsaw, I954, p. I35.

${ }^{23}$ Andrzej Mandalian, Słowa na codzień, Warsaw, I953, pp. 9-I6.

24 Nowa Huta, p. 45. 
'And here the globe becomes brighter - / our joy and our concern, / the hope of the world comes from Moscow / as the wave of light. // And the Vistula river and home are closer / the faces of the friend and the enemy you will see better / and it is better to live / and it is better to work. ${ }^{25}$ Because in Socialist Realism the whole universe supports Communism, even the sun participates in the May Day parade: 'The light from the Kremlin hits you, / its smile on your face / high above us in the parade, / the sun is marching, / Sun - our comrade. ${ }^{26}$ It does not have to be the sun that is the source of light, just as long as the light comes from Moscow. Like Słucki, Henryk Gaworski (born I928) employs the metaphor of light coming from Moscow, but this time it is the red star on top of the Kremlin that illumines the Communist world, a new version of ex Oriente lux: 'Above the Kremlin the rays of the star / That never dies. ${ }^{27}$

The dark-light opposition also figures widely in Polish fiction. In Joanna Żwirska's (I9I I-I988) short story Światło (Light, I95I), a poor, backward village becomes transformed by the installation of electricity. 'We have light and the wireless in our village and we will have a new life now, ${ }^{28}$ says one of the characters, and the reader is meant to infer that electricity will transform life not only in this village but throughout the land.

The metaphor of light is so powerful that uneducated manual labourers seem to use it in their everyday discourse spontaneously, without any pressure from the authorities: according to a biography of President Bolesław Bierut published at the height of Socialist Realism in I952, one worker, having seen Bierut during the reconstruction of a destroyed bridge, is supposed to have declared: 'It became brighter and warmer that evening. ${ }^{29}$

The only exception to the negative connotations of darkness is the positive association with the darkness of coal and coalmining. Coalminers were among the greatest heroes of Socialist labour (but only after the I950s; earlier the title had belonged to bricklayers), and during the I970s they become an icon of Polishness and the very face of Poland. As heroes of Socialist labour, coalminers are portrayed as manly and utterly devoted to their dangerous underground world. Their darkness and greyness is attractive because it is tied to sacrifice and struggle in the name of socialism. In a poem Wegiel (Coal, I95 I) by a young engineer from the Academy of Steel and Coalmining in Cracow, darkness represents not only the dangers hidden 600 metres below ground, but also the eternal struggle of man and Nature because coal is 'future energy' that can be excavated only thanks to the miners' 'blood and sweat'. He writes: 'They wear grey jackets / And they themselves are grey / Like the pavements of their towns. / You can't see the faces under the helmets. / They wait / They descend at six. ${ }^{30}$

Other than that, grey rarely appears among the colours employed by Socialist Realist writers because of its negative connotations. There are exceptions, such as Gałczyński's poem Piękne dziewczyny (Beautiful Girls, I952). Although Gałczyński admires the new reality, where young female workers work on jobs traditionally reserved for men, the poem also suggests the dullness of post-war reality that he attributes to 'the greyness of our firmament'. This realistic

25 Arnold Słucki, Słońce nasz towarzysz, Warsaw, I95 I, p. 39.

${ }^{26}$ Ibid., p. 39.

${ }^{27}$ Henryk Gaworski, Przed nami życie, Warsaw, I95 I, p. I7.

${ }_{28}$ Joanna Żwirska, Światło. Opowiadania, Warsaw, I95 I, p. 9I.

29 Józef Kowalczyk (ed.), Bolesław Bierut. Życie i działalność, Warsaw, I952, p. I04.

${ }^{30}$ Jan Zechenter, unpublished poem, I95I. 
observation of the greyness of the industrial landscape was, however, acceptable simply because it implied industrial progress and was thus a popular motif, as revealed especially by picture postcards. ${ }^{3 \mathrm{I}}$

\section{The Realistic Use of Colour in Literature between 1956 and 1976}

Three years after Stalin's death in March 1953, Socialist Realism ceased to be offcially sanctioned by the Communist Party and the thaw allowed more artistic freedom. The years from I956 to I970 are called in Polish 'our little stabilization' after the title of a play by Tadeusz Różewicz (born I92I). The increase in political and artistic freedom allowed for the beginning of discussions on Marxism, existentialism, phenomenology and realism. ${ }^{32}$ Some Marxist critics, for example, Stefan Żółkiewski (I9I I-I99I), however, still hoped for a Socialist Realism that would reflect the reality of I960s without being either dogmatic or schematic. ${ }^{33}$

By the late I960s, the role of censorship had changed and the censor's decision could be altered if the writer had the right connexions in the Party. In general, the Party felt that there was no need to force society to speak with one voice. As a result, the Main Office of Control made its own rules: 'what all this meant, for journalists and editors, was that what went on in the Main Office was unpredictable and mysterious, not definitive. ${ }^{34}$ Still, in general, censorship did not seek to influence the presentation of colour as it had typically done in the I950s. ${ }^{35}$

Some writers responded to the political and social changes by creating an opposite, 'black' legend in place of the obligatory 'bright' legend of the early I950s. The 'black' refers, however, not to the world surrounding the characters but mostly to their own attitudes and behaviour. The major figure of the 'black' legend was Marek Hłasko, who died in mysterious circumstances in I969. Although his first published work was a Socialist Realist short story Baza Sokołowska (Camp Sokołów, I95I), his wider literary output created the character of an unhappy, disillusioned young man, 'a representative of the Polish "angry young man", ${ }^{36}$ who rebels against society, a man living in an ugly world of poor, scruffy neighbourhoods where the men are always drunk. Hłasko's protagonist is not interested in the historical, but only in the here and now, so his rebellion leads to existential, not political suffering.

Despite the clearly pessimistic message of Hłasko's work, his use of colour is not connected with the mood or climate of a story. On the contrary, the often colourful world is a place in which the ugliness of human behaviour becomes apparent. Hłasko's presentation of colour represents the general approach to colour in literature from the I960s to the mid-I970s:

${ }^{31}$ For example, on period postcards Cracow was shown as the background to Nowa Huta, with the latter's smoking chimneys suggesting not only the importance of the new town's industry but also the transforming power of Communism. See Andrzej Chwalba, Dzieje Krakowa. Kraków w latach 1945-1989, Cracow, 2004, p. 209.

${ }_{32}$ Marian Kisiel, 'Przełom I955-I959 w literaturze polskiej', in Krzysztof Krasuski (ed.), Cenzury i przełomy. Studia o literaturze polskiej XX wieku, Katowice, I994, pp. 84-98.

33 Alina Brodzka, 'O pojęciu realizmu w powieści XIX i XX wieku', in H. Markiewicz (ed.), Problemy teorii literatury. Seria 1: Prace z lat 1947-1964, 2nd edn, Wrocław, I987, p. 302.

${ }^{34}$ Jane Leftwich Curry (ed. and trans.), The Black Book of Polish Censorship, New York, I984, p. I7.

35 See Joanna Hobot, Gra z cenzura w poezji Nowej Fali 1968-1976, Cracow, 2000.

${ }^{36}$ George Gömöri, Magnetic Poles. Essays on Modern Polish and Comparative Literature, London, 2000, p. 4I. 
life might be difficult, men might be drunkards and abusers and women might prostitute themselves, yet the sky remains blue and the grass green.

The two decades $1956-76$ were a period of which it is fair to say that colour was presented as corresponding to the Polish reality of the time. Without going into detailed discussion of what then constituted realistic literature, I maintain that during these years it was possible to employ colour terms realistically because literature, having been freed from its earlier political obligations, was allowed to present even previously taboo topics in a new, realistic light. For instance, the West might be now presented as beautiful or ugly depending not on politics but on the weather. In Stanisław Dygat's (I9I4-I978) novel Dworzec w Monachium (The Station in Munich, I973), set during the Second World War, one of the characters remarks: 'Isn't it true that the Alps are beautiful? And that the world here is so beautiful? Isn't it strange that the world here, their world, can also be so beautiful?' 37 Yet when it is raining, Munich is presented simply as grey and dirty, without its earlier appeal: 'people walk, cars on streets. A bank. A coffee chop. Apfelkuchen mit Sahne. People carry things. Drizzle, everything is grey, grimy. ${ }^{3} 8$

Dygat's story takes place in the reality of socialist Poland, but this is a different Poland from that of the I950s. People can travel, although that requires knowing the right people in the right places, and although the West is colourful ${ }^{39}$ and was beautiful even during the Second World War, colours are presented as colours pure and simple. What is more, the West as presented by Dygat is similar to the Eastern Bloc when the narrator observes that some buildings in Munich could equally well be located in 'Poznań, Wrocław, Szczecin or in the Warsaw borough of Praga. But not in Cracow, not in Gdańsk and not in Lublin.'40

Even when a story presents a tragic or disastrous situation, as in Andrzej Kijowski's (I92885) novel Oskarżony (The accused, I973), where the husband of a mentally sick woman is accused of her murder, the colour in the novel retains its realism: the narrator looks outside to see 'a clear, bright night'. ${ }^{4 \mathrm{I}}$ The lot of the family has no bearing on the beauty of the place: it is man alone who is responsible for his actions. The outside world, the colours of the sky, the colour of the flowers or the dresses that women wear are independent of what the main character feels.

By 1974, when two poets, Julian Kornhauser (born I946) and Adam Zagajewski (born I945), produced Świat nieprzedstawiony (The world not represented), in which they accused the majority of Polish writers of not portraying contemporary Poland properly, the political and social situation was already deteriorating. The critics argued that Polish literature was not meeting its fundamental moral obligation because it was failing to provide any detailed description or analysis of 'human types and human experiences'. ${ }^{22}$ They were not interested in old-fashioned realism; instead they demanded an analysis of contemporary reality and an examination of its social roots.

Because of the censorship, Kornhauser and Zagajewski's analysis could not include any 'banned' writers who were concerned with the social aspects of post-war Communist reality.

37 Stanisław Dygat, Dworzec w Monachium, Warsaw, I973, p. 44.

$3^{8}$ Ibid., p. 55 .

39 Ibid., p. 52.

$4^{\circ}$ Ibid., p. 94.

${ }^{4}$ I Andrzej Kijowski, Oskarżony $i$ inne opowiadania, Warsaw, I973, p. I24.

${ }^{42}$ Julian Kornhauser and Adam Zagajewski, Świat nie przedstawiony, Cracow, I974, p. 36. 
Such writers included Kazimierz Orłoś (born I935), whose Cudowna melina (A wonderful joint, I973) was published by Kultura in Paris, Jerzy Andrzejewski (1909-83), whose Miazga (Pulp) could not appear with an official publishing house until I98I; the later stories of Marek Nowakowski (born I935) had also to be left out of the account. Each of these writers described the social and political roots of Polish reality exactly as Zagajewski and Kornhauser had demanded in their analysis, but their works were simply not accessible and, being by proscribed authors, could not be discussed in official publications.

Kornhauser and Zagajewski also argue that 'the richness of colour' that typified the works of certain poets, such as Jerzy Harasymowicz (I933-99), was the very antithesis of realistic. Harasymowicz, who created an extraordinarily colourful dream-world rooted in the past, folk art, wooden churches and the magic of the borderlands, moved, according to the critics, towards the garishness of kitsch and thus rejected reality altogether. ${ }^{43}$ Yet, when Harasymowicz's first published work appeared in I956, his colourful world had its roots in a definite place, wooden village churches and the Lemko (Ruthene) people living in the foothills of the Carpathians; such places had been completely absent from Polish literature during the period of Socialist Realism. It was only later that his poetry became reduced to the same, constantly repeated imagery which offered little new to the possibilities of colour as an organizing principle.

Kornhauser and Zagajewski charged other poets who portrayed marginal or ugly aspects of reality, especially Miron Białoszewski (I922-83) and Stanisław Grochowiak (I934-76), with having also moved towards mere stylization, a fascination with ugliness and, in general, a fascination with the peripheral. Kornhauser and Zagajewski suggest that the 'grey, unattractive elements in [the latter's] poetry that are generally not considered poetic' were simply a device that enabled them to reject reality altogether and so avoid discussing it. However, Białoszewski's absorption with the undignified and his reluctance to focus on the moral aspect of colour not only suggest the assertion of his artistic freedom, but also constitute a realistic portrayal of regions and aspects of life that had previously been ignored. ${ }^{44}$ According to Zbigniew Bieńkowski, 'greyness and the ugly aspects of the world' became, in Białoszewski's poetry, an element of surprise, precisely because of its widely assumed inability to fascinate. ${ }^{45}$ In the poem 'Szare eminencje zachwytu' (Eminences grises of exaltation, I956) Białoszewski extols, for instance, the beauty of a common or trivial objects such as a colander and 'a grey - almost sleepy' stove and even the grey hole left after the stove is taken away (expressed as nagaszarajama 'baregreyhole') drawing on the similarity between the physical and metaphysical..$^{6}$

\section{The Re-politicization of Colour: The Grey Period (1976-89)}

After Gierek came to power in I970, censorship and the bureaucracy burgeoned and control of the written word was rigorously re-imposed. Although the early Gierek years were greeted with hope, the latter part of the I970s exposed a multitude of social problems. Everyday reality — food shortages, long queues and the constant bombardment of propaganda -

\footnotetext{
43 Ibid., p. 80.

${ }^{44}$ Ibid., p. 72.

45 Zbigniew Bieńkowski, Poezja i niepoezja. Szkice, Warsaw, I967, p. I I9.

${ }^{46}$ Miron Białoszewski, Trzydzieści lat wierszy, Warsaw, I982, pp. 29, 48.
} 
became too distressing and onerous to be ignored. People felt poorer and less hopeful about the future; many of them lived in huge, grey, oppressive concrete buildings that make them feel alienated. What passed for 'normal life' was perceived as grey, as in an anonymous song sung in the summer of I980 during the strike in the Gdańsk shipyards: 'see the faces of our mothers and wives, / as grey and withered as our life.' ${ }^{47}$

Pessimism grew and Konwicki remarks that the I970s 'turned the attention of literature toward social problems'48 and that this shift was prompted not simply by deteriorating political and economic circumstances, but above all by the atmosphere of despair that attended that decade. According to Kazimierz Orłoś by the end of the I96os: 'everything indicated that the country was caught again in a spider's web, just as in the days of Stalin. The methods had changed; the character of politics had changed; new people had come, but the course of political developments and their base had remained unchanged.' ${ }^{49}$ It is unsurprising, then, that in I976, a group of dissident intellectuals founded the first anti-Communist civil group in Poland, the Workers' Defence Committee (KOR). Meanwhile, the government introduced ration coupons in response to shortages of basic foodstuffs. The overwhelming presence of grey in Polish literature of the time reflected the political and social mood of society and was not a literal depiction of reality, which in many respects had been improving since Gierek came to power.

In general in European culture, grey is not an uplifting colour. Rossotti, for example, calls it 'unappealing', ${ }^{50}$ while Ruskin, connected it with distress. ${ }^{5 \mathrm{I}}$ Grey, however, has often captured the imagination of poets and painters. The paintings of Claude Monet, Odilon Redon or Georges Seurat, whose pointilliste technique produced a greyed effect, explored numerous shades of grey. Ludwig Wittgenstein was intrigued by the idea of 'luminous grey', which he believed could not exist. ${ }^{2}$ Among contemporary painters, Jasper Johns and Cy Twombly employ grey in many of their paintings, for example, Twombly's Hero and Leander (part II), I984, Goethe in Italy (Scene II) (I978), Virgil (I972) or Orpheus (I979). In Western literature, to give one example, but a telling one, grey became closely associated with totalitarianism after George Orwell's 1984 with its 'grey and barren world', 53 'drab-grey wholly unaesthetic surroundings' 54 and the 'bowed, grey-coloured, skeleton-like thing's5 that before the interrogation was Winston Smith. More important, in Orwell's novel grey conveys not just the oppressive surroundings, but the sense of utter defencelessness in the face of the system and the absolute lack of hope that any change could come about.

The clearly visible presence of grey begins with Tadeusz Konwicki's novel Wniebowstapienie (Ascension, I967) set in a realistically portrayed Warsaw. In the novel, the greyness is all-pervading and is connected more with the mood of the people than with the season.

47 Documentary by TVP Polonia broadcast on August 3 I 2006.

$4^{8}$ A. J. Liehm, 'Conversation with Tadeusz Konwicki', Cross Currents, I982, p. 84.

49 Kazimierz Orłoś, Historia 'Cudowej meliny', Paris, I987, p. 25.

so Hazel Rossotti, Colour: Why the World Isn't Grey, Harmondsworth, I983, p. 227.

${ }_{51}$ The Works of John Ruskin, ed. by E. T. Cook and A. Wedderburn, London, I903, p. 404.

52 Ludwig Wittgenstein, Remarks on Colour, trans. by L. L. McAlister and M. Schättle, Oxford, I978, p. $47 \mathrm{e}$.

53 Ruth Vinz, '1984: Intricate Corridors within a Barren World', The English Journal, 6, I983, p. 39.

${ }^{54}$ Harold J. Harris, 'Orwell's Essays and 1984', Twentieth Century Literature, 4, I959, p. I 55.

55 George Orwell, 1984, New York, I99I, p. 274. 
Unspecified fears, the constant police presence on the streets, the darkness despite the bizarre neon lights that pepper Warsaw in Wniebowstapienie, all create an atmosphere of oppressiveness and greyness. Greyness does not suggest the mediocrity of ordinary life as it does conventionally, but rather people's inability to escape a political reality.

Because of Konwicki's novel, grey became permanently associated with the colour of the Palace of Culture, a clear sign of political subjugation that during the I950s was hailed as a 'building of light'. ${ }^{66}$ Now, in 1967 , the building is as grey as the reality of which it has become a part. A decade later, in the novel Mała apokalipsa (A minor apocalypse, I979) which was published by an underground press, the Palace of Culture becomes an emblem of oppression and depression: 'a monument to arrogance, a statue to slavery, a stone layer cake of abomination.' ${ }^{57}$ The greyness that permeates the Warsaw of Wniebowstapienie and Mała apokalipsa becomes the colour of new apartments in concrete buildings, which in Konwicki's novels imply spiritual homelessness, and sets the mood of futility, gloom and hopelessness.

The Nowa Fala dominated Polish verse in the I970s; ${ }^{58}$ the poets employed a language moulded by political propaganda because they intended to emphasize the abuse of language by the system while also drawing attention to socio-political reality. A lack of reference to colour is readily noticeable in their poetry, especially in works by Kornhauser, Zagajewski and Stanisław Barańczak (born I946). Other poets of the movement, among them Jacek Bieriezin (I95 I-93), Bronisław Maj (born I953) and Ryszard Krynicki (born I943), focused on the deteriorating political situation and presented Poland as a prison; in Polish literature prisons are traditionally presented as grey. ${ }^{59}$ In one poem, 'Jesteście wolni' (You are Free, I98I), Krynicki equates Poland with prison: "You're free," says the guard, / and the iron gate shuts / this time from this side. ${ }^{60}$ The prison in socialist Poland is grey because it is made of grey concrete and surrounded by barbed wire, an image that reverberates in poems by many poets, for example, Krynicki's 'the concrete wall/the barbed wire and the steel gate' or Jan Polkowski's (born I953) poem 'Free: In a free country' (Wolny: W wolnym kraju) ${ }^{61}$

For many poets, and especially for Barańczak, the use of grey was not only an ethical response to reality but also a reaction to the fact that political and social realities seemed to have been accepted by 'the grey man', the 'N.N.' in Barańczak's verse. ${ }^{62}$ As one critic, Charles Kraszewski, concludes: 'Life in hell is not a continual round of terror; one of the most refined tortures is this greyness, this omnipresent mediocrity, in which eternal damnation has been

${ }^{56}$ Wojciech Tomasik, Inżyniera dusz: literatura realizmu socjalistycznego $w$ planie propagandy monumentalnej, Wrocław, I999, pp. I00-07.

57 Tadeusz Konwicki, A Minor Apocalypse, trans. by Richard Lourie, New York, I984, p. 4.

${ }^{58}$ It is generally accepted that the Nowa Fala ended in 1976 with the creation of an underground press in Poland, although the writers concerned continued to write and publish.

59 As early as I938 Fik calls a prison 'a grey house': Ignacy Fik, Wybór pism krytycznych, ed. by Andrzej Chruszczyński, Warsaw, I96I, pp. 220-23. In his I957 poem 'Ornamentatorzy' (Decorators) Zbigniew Herbert (I924-98) writes of those who refuse to see the reality and prefer to paint 'the grey prison wall' pink.

${ }_{60}$ Ryszard Krynicki, 'You're Free', in S. Barańczak and C. Cavanagh (eds and trans), Spoiling Cannibals' Fun. Polish Poetry of the Last Two Decades of the Communist Rule, Evanston IL, I99 I (hereafter Spoiling Cannibals' Fun), p. I44.

${ }^{61}$ Ryszard Krynicki, 'The Wall', in Spoiling Cannibals' Fun, p. I45; [Anon.], Poezja stanu wojennego. Antologia, Warsaw, I982, p; 63.

${ }^{62}$ Krzysztof Biedrzycki, Swiat poezji Stanisława Barańczaka, Cracow, I995, p. I I. 
superseded by the official censure. ${ }^{63}$ The very reality of Barańczak's external world is grey and unpleasant. Early morning in Barańczak's poems is a time when the police begin to search people and their flats and also the moment when the ugliness of the world becomes most clearly apparent: 'It's morning. And a bed. And a room / in a hotel, a grey thaw outside / the window, the paving / of the street, business trip, unpleasant / taste in the mouth, blinding / light of the morning. / N.N. wakes up' ${ }^{64}$ For Barańczak, this lack of ethical clarity, the "greyness of the intermediary sphere ${ }^{6 s}$ provided Polish poetry with an opportunity, since it allowed for greater poetic freedom. This sphere, with its ambiguity and a lack of clear-cut boundaries, suggested a great deal about Poland and the Poles and thus for Barańczak was a form of social study. The 'grey man enslaved by the system' was not, however, an object of ridicule for the poet, who instead explores the drama of choosing between Communism and conformism. ${ }^{66}$

The Nowa fala was in general concerned with the ethical weakness of 'the grey man', who sometimes thinks the way the Party wants him to think. In Stanisław Stabro's (born I945) poem ' $V$ ', from the cycle of poems 'A to Polska w lasnie' (This is Poland) uneducated parents advise their child 'never to get involved in anything' and trot out the slogan that 'Poland is a great thing' in the same breath, without realizing that the two statements are contradictory. ${ }^{67}$ 'The grey man' of the I970s has given up fighting because he is slowly succumbing either to sovietization, as are the characters in Konwicki's novels, or to the dishonesty of those who, in Stabro's poem 'Budzi mnie po nocy' (It wakes me at night, I989), buy one crystal vase with a picture of the Polish Pope and another with a portrait of General Jaruzelski.

The greyness of life parallels the contemporary lack of clear ethical boundaries. Most important, however, it marks the connexion between grey and the realm of ethics in literature of the era. This is especially visible in the verse of Zbigniew Herbert, a poet who is exceptionally sensitive to colour ${ }^{68}$ and contrasts the world's beauty with the greyness of oppression in, for example, the poem, 'Modlitwa pana Cogito - podróżnika (Prayer of Mr. Cogito - Traveller, I98I). In his verse, which is deeply rooted in ethics and the notion of moral obligation, Herbert often dispenses with colour altogether, that is, in essence, he stays with greyness, as in 'Potwór Pana Cogito' (The monster of Mr. Cogito), a poem that contrasts the clarity of early Christian values with contemporary ethical vagueness. ${ }^{69}$ The modern dragon that Mr Cogito attempts to slay cannot be seen through the dense grey fog, unlike the dragon slain by Saint George in broad daylight. The contemporary dragon looks different: 'he sits in the low / saddle of a valley / covered with thick fog // through the fog it is impossible to perceive / fiery eyes / greedy claws / jaws // through fog / one sees only / the shimmering of nothingness // the monster of Mr. Cogito / has no measurements // it is difficult to describe / escapes definition // it is like an immense depression / spread out over the

${ }^{63}$ Charles S. Kraszewski, 'Eschatological Imagery in the Early Verse of Stanisław Barańczak', The Polish Review, I, 200 I, p. 54.

${ }^{64}$ Stanisław Barańczak, Wiersze prawie zebrane, Warsaw, I98 I, p. 37.

${ }^{65}$ Stanisław Barańczak, Zaufać nieufności. Osiem rozmów o sensie poezji 1990-1992, Cracow, I993, p. I I8.

${ }^{66}$ Ibid.

${ }^{67}$ Stanisław Starbo, Korozja, Wiersze z lat 1982-1984, Warsaw, I989, p. 7I.

${ }^{68}$ Zbigniew Herbert is the author of two collections of essays on art: Barbarzynica $w$ ogrodzie (Barbarian in the Garden, 1962) and Martwa natura z wędzidłem (Still Life with Bridle, I993).

${ }^{69}$ Herbert's use of grey is complex and beyond the scope of the present article. 
country'. ${ }^{70}$ The Poland of the late I970s appears ugly and grey by association with pessimism, depression and melancholy. Even places that were once considered beautiful and colourful became grey in socialist Poland. Kazimierz Orłoś writes:

Tomaszów, where we stopped for breakfast, appeared depressingly dirty, grey and poor. 'And maybe, my beloved, we might stop in Tomaszów for one day,' sang Ewa Demarczyk in Julian Tuwim's poem. Before the war Tomaszów might have looked different, but now we saw a dirty bus station, men drunk at nine o'clock in the morning, tables in bars, tired faces, grey streets. Grey snow. ${ }^{71}$

Orłoś stresses that this is the real socialist Poland, not the one peddled by official propaganda in newspapers, journals or on television: a world of forgotten and poor towns such as Piotrków, Rozprza or Radomsko that once belonged to Russia. Their world is 'grey, even more sad' that the greyness of Tomaszów described earlier. ${ }^{72}$ Similarly, Anatol Marek Lipiec writes in Kultura, a periodical that appeared in Paris, about the Poles he sees in Poland: 'those Orwellian proles, grey, dirty, sloppy and untidy, standing in queues or in their long wait at bus stops. ${ }^{73}$ Again, in I977, Bolesław Sulik writes to Kultura about 'these grey bricks of Polish reality' despite describing at the same time the actual colours of the white Franciscan church, the green square in the centre of the town and a colourful relief on the façade of the House of Culture in Radomsko, reflecting thereby the overall feeling of depression and not the visual aspect of Polish reality. ${ }^{74}$

The connexion between Communism and greyness was becoming standard around that time as well. Important, although it stresses the visual aspect of a system, it also suggests the emotional impact of that system. Compare the following examples: in I977 in London, Aleksander Wat (I900-67) published his memoirs entitled Mój wiek (My Century), in which he emphasized the dramatic change from the colourful and free pre-war Polish Lwów (Lviv, Lemberg) to the greyness of the city during the Soviet era: '[Previously Lwów] was very colourful, very exotic. [...] Well, the Soviets had barely arrived, and all at once everything was covered in mud (of course it was autumn), dirty, grey, shabby. ${ }^{75}$ In Julian Stryjkowski's (I909-96) autobiographical novel, Wielki strach (The great fear; published privately 1979), dealing with the years I939-4I that he spent in Lwów under Soviet occupation, the author suggests the influence of the system by means of the overpowering sense of greyness even when other colours are present. For Stryjkowski, greyness imposes an emotional quality that overrides the purely visual aspects of a colour: when Soviet products appeared in shops in occupied Lwów, they were perceived as grey no matter what their real colours: 'But no one was buying these products. They were shoddy, grey, too long. Even the toys for children, little bunnies and teddy bears made out of yellow plush, little soldiers and tanks make of cardboard or tin painted red. The best that they had. ${ }^{{ }^{7} 6}$ Similar associations were made by an

\footnotetext{
$7^{\circ}$ Zbigniew Herbert, 'The Monster of Mr. Cogito', in Spoiling Cannibals' Fun, p. Io3.

${ }^{71}$ Kazimierz Orłoś, Historia 'Cudownej meliny', p. 62.

72 Ibid., p. 63.

73 Anatol Marek Lipiec, 'Totalitaryzm na co dzień', Kultura, 6, I979, p. 87.

74 Bolesław Sulik, 'Osoby towarzyszące', Kultura, 5, I977, p. 58.

75 Aleksander Wat, My Century. The Odyssey of a Polish Intellectual, trans. by Richard Lourie, Berkeley CA, I988, p. IO4.

${ }^{76}$ Julian Stryjkowski, Wielki strach; To samo, ale inaczej, Warsaw, I990, p. I36.
} 
Israeli writer born in Poland, Miriam Akavia (born I927), when she wrote of the contrast between the colourful, pre-war Cracow, where she was raised, and Lwów, where she spent the occupation: 'I remember that other Lwów. Grey, sad, scary.'77

The greyness introduced by Communism encompassed the entire Eastern Bloc: its advance formed a grey wave that took other colours over. The Lithuanian émigré Tomas Venclova (born 1937) wrote an essay in I979 in which he discusses medieval and Baroque Vilnius (Wilno, Vilna) encircled by the Soviet reality that was erasing the multicultural uniqueness of pre-war Vilnius. Venclova notes that 'The whole city was surrounded by grey, standardized housing which made the garrison architecture of Tsarist times appear quite decent. These houses effectively ruined the Antokol district and began to encroach on the historic centre, right up to Museum Street'. ${ }^{7}$ In Andrzej Stasiuk's (born 1960) novel Dukla (Dukla, I997) the narrator drives across the border into post-Communist Slovakia just to see what was left of the once glorious socialism: "fields and somewhere in the middle of them a lone concrete building. Nothing else, only the building: grey, angular, dilapidated.' ${ }^{79}$

The deteriorating political situation worsened further with the imposition of martial law on December I3 I98I. Where I950s literature was ruled by an association between red and Communism and I970s by greyness, literature of the period of martial law focuses on two colours: black and white, which now suggest a clarity of moral choices after December I3 I98 I. In poetry written during the first year of martial law the meaning of each colour can be easily decoded. White is used to portray realistically the cold and snowy winter of I98 I but, being associated with purity and nineteenth-century Polish messianism, it also constitutes an image of the suffering endured by the Poles in the name of freedom. Similarly, black refers to the actual black glasses worn by General Jaruzelski, ${ }^{80}$ the black Volgas (the cars driven by the secret police), but most of all, to a crow, wrona, through the acronym WRON(-a) for the Military Council of National Salvation (Wojskowa Rada Ocalenia Narodowego) that took power after December I 3 I98 I. It also suggests outright condemnation of those responsible for imposing martial law; this found its popular expression in a saying about the struggle between the white eagle, symbol of Poland, and the crow: '[the] Crow will not defeat the eagle.' Since poetry of the martial law period also draws a connexion between that time and Christmas Eve, when 'again we share a black wafer' of Polish fate, ${ }^{8 \mathrm{I}}$ this not only hints at the nation's desperation but, more importantly, it links I98 I - through the identification of freedom with the Catholic faith - to the tradition of Polish patriotic poetry.

However, the use of grey did not disappear from the poetry in the period of martial law either. It is very much there when 'you walk sadly along a Warsaw street / where you pass boys in grey uniforms ${ }^{82}$ or when one is in 'a grey nervous crowd' in 'a dead city'. ${ }^{83}$ The grey corresponds to the overwhelming pessimism that followed in the wake of I98I, while the

77 Miriam Akavia, 'Zawiedziona miłość', Stanisław Obirek, 'SJ rozmawia z Miriam Akavią'<http://www. dialog.org/dialog_pl/miriam-akavia-rozmowa.htm>, [accessed June Io 2007].

${ }^{78}$ Tomas Venclova, Forms of Hope. Essays, Riverdale-on-Hudson, NJ, I999, p. 23.

79 Andrzej Stasiuk, Dukla, Czarne, I997, p. 73.

${ }^{80}$ Jan Marty, 'I4.I2.8I', in [Anon.], Poezja stanu wojennego. Antologia (hereafter Poezja stanu wojennego), London, I982, p. 24.

${ }^{8 \mathrm{I}}$ M.K., 'L'Ordre regne à Varsovie', in Poezja stanu wojennego, p. 79.

${ }_{82}$ Anon., in Poezja stanu wojennego, p. 84. The uniforms of the Polish milicja were actually blue.

${ }_{33}$ Bronisław Maj, untitled poem, in Stanisław Barańczak (ed.), Poeta pamięta. Antologia poezji świadectwa $i$ sprzeciwu, London, I984, p. 359. 
black-white dichotomy strengthens the image of the struggle between good and evil while, at the same time, underlining the simplification of verse written under martial law.

The greyness of the late I970s and the depression of the period of martial law was almost uniform, but there was one major exception: an underground anarchist movement, which began in I98 I in Wrockaw: 'a moment of joy, some freedom in the greyness of our yonder existence, ${ }^{84}$ according to Janusz Onyszkiewicz, one of the opposition leaders. Orange Alternative (Pomarańczowa Alternatywa) painted little dwarfs on city walls and organized absurd happenings that enjoyed tremendous popular support; these succeeded in embarrassing the authorities as when, for instance, toilet paper, a basic commodity that was impossible to obtain in the normal way, was handed out free. The movement, whose colour is supposedly the result of mixing red (Communism) with yellow (the Catholic Church), added an element of the grotesque and surreal to the everyday drabness, but it did not find its representation in literature. ${ }^{85}$

\section{The Second Creation and the Return of Colour after 1989}

The Poland of the late I970s and the early I980s was universally perceived as grey. The shock of encountering the West with its bright colours was documented by Barańczak, who, while in the West in I984, remarked that the average East European has 'never expected houses to be painted so brightly purple or blue, school buses to be so warmly yellow, street signs to be so invitingly green'. ${ }^{86}$ Indirectly, Barańczak's observation emphasizes the extent of greyness in Communist Poland but only Poles have commented on the extent of greyness. In 2002, Vernissage and the Bloxham Galleries in London held an exhibition of young female Polish painters entitled Allergy to Grey, where the common denominator was the enjoyment of colour and its association with freedom as expressed by the liberated female ego of the post-Communist Poland. ${ }^{87}$

After the first free elections in I989, writers who had not travelled abroad experienced shock when 'the West came to Poland' with all its colourful products. The opposition between the grey of Communism and cheerful post-I989 colours quickly became a popular metaphor of the change, and was so employed in everyday discourse. ${ }^{88}$ Colours suggested the West, freedom and happiness as they became synonymous with the new times, the era of consumerism, and symbolic of wealth, even if that wealth was illusory. The Communist past was now routinely described as 'grey', as in Andrzej Stasiuk's stories where socialism is summarized as 'the greatest dispenser of greyness'. ${ }^{89}$ Similarly, in the novel Madame (Madame, I998), which became celebrated as a great literary event and was soon translated into twenty languages, the author, Antoni Libera, describes the Poland of I960s as having been drab and grey. This

${ }^{84}$ Janusz Onyszkiewicz, 'Orange Alternative at the European Parliament in Brussels', June 2 I $2005<$ http:// pomaranczowa-alternatywa.republika.pl/expo\%20eng.thml>, [accessed May I 5 2007].

${ }_{85}$ Bronisław Misztal, 'Between the State and Solidarity: One Movement, Two Interpretations - The Orange Alternative Movement in Poland', The British Journal of Sociology, I (I992), pp. 55-78.

${ }^{86}$ Stanisław Barańczak, Breathing Under Water and Other East European Essays, Cambridge MA, I990, p. 9.

${ }^{87}$ The Bloxham Galleries, London, October I-25 2002. Paintings by Urszula Kaczorowska, Ilona Herc, Monika Stolarz, Angieszka Kwapisz and others.

${ }^{88}$ Joanna Siedlecka, Wypominki. O pisarzach polskich, Warsaw, 2003, pp. 263, 269, 293.

${ }^{89}$ Andrzej Stasiuk, Opowieści galicyjskie, Cracow, I995, p. I3. 
opposition is rendered even more evident through the contrast that Libera erects between the reality of 'our small stabilization' and the French connexion of the main character, a beautiful young woman who teaches French and who struggles to leave Warsaw and move to Paris. For Libera, it is not only 'the grey concrete of the schoolyard', ${ }^{\circ}$ 'the grey, boring and embittered teachers', ${ }^{11}$ as opposed to Madame's 'colourful scarf at her neck', ${ }^{92}$ but the entire contrast between 'grey laundry soap instead of Chanel No. 5', ${ }^{93}$ that is, between drabness of Communist Poland and the beauty and sophistication of the West.

The use of bright colours in literature after I 989 can thus be compared to a second creation of the world, when the old transforms itself into the new. The old, grey kiosk in Stasiuk's story becomes now 'the most colourful place within a fifteen-kilometre radius' because 'this creation of the world does not take place in time or in space but rather in the domain of colours'. ${ }^{44}$ The man responsible for the change, Władek, once a poor father of twelve children, now becomes a priest of the new religion 'because, what else is the magus Apollonius from Soloviev's novel doing, if not creating from thin air the purest and brightest of colours? Colours such as the world has never seen before?'95

The clash between the old and the new, the grey and the colourful, between the drab and the brightly coloured objects the draw attention to themselves as part of the new economy that stresses selling and possessing have tragic consequences because the change from absence of colour to the new colours constitutes a surrender, as in Tomek Tryzma's controversial novel Panna Nikt (Miss Nobody, I994). Seeing all those gaily coloured Western objects makes Miss Nobody reflect on how mediocre her life had been and would continue to be, because she is and feels poor. She allows herself to be enticed, but pays dearly for her enticement by jumping from a window of her parents' flat in a grey, concrete block to 'liberate herself from the greyness of her old life'.$^{96}$ Moreover, in the struggle between a simple, achromatic God and the multiplicity of new, Western colours, God loses:

on cupboards, TV sets, shiny furniture stand empty rows of cans of DAB beer, boxes that had once held Maxim Brandy, rows of boxes of Gold Wiener, orange juice, empty cubes of which the contents are not necessarily known. They stand a little below the old holy pictures: Saint Joseph in the colour of sepia, the Mother of God in faded blue, the black-and-white Holy Father. One Mary, one Joseph, one pope against such a variety, such a multiplicity. ${ }^{97}$

\section{Conclusion}

Despite its limited length, the article examines the meaning of colour(s) throughout post-war Polish literature. The hindsight that separates the reality of Communist greyness from how today's reader perceives it can easily lead to over-simplification, but it can also lead to a deeper understanding. In 2000, the gallery of contemporary art in Warsaw, Zachęta, staged an exhibition of everyday objects, photographs, posters and films entitled 'In Grey:

90 Antoni Libera, Madame, trans. by Agnieszka Kołakowska, Edinburgh, 2000, p. I67.

9I Ibid., p. 43.

92 Ibid., p. 29I

93 Ibid., p. 200.

94 Stasiuk, Opowieści galicyjskie, p. I 3 .

95 Ibid., p. I6.

${ }_{96}^{6}$ Jerzy Jarzębski, Apetyt na przemianę. Notatki o prozie wspótczesnej, Cracow, I997, p. I04.

${ }_{97}$ Stasiuk, Opowieści galicyjskie, p. I6. 
I956-I970', in part to remind the public about the reality of life under socialism, and partly to bear witness to the past as it disappears rapidly from view. The uneven, grey paving of the streets in the I96os that was part of the Zachęta exhibition, 'the saddest grey paving in the world', ${ }^{8}$ was hailed by critics as an epitome of socialism: the paving was supposed to make life easier, but it was actually a health hazard because of its constant poor state of repair.

Hindsight also makes it possible to distinguish different shades of the Communist grey. For instance, a Warsaw that was almost completely reconstructed after the Second World War and was home to a large percentage of the new intelligentsia and the new working class was greyer and more socialist than, for example, Cracow with its old-fashioned intelligentsia, Catholic institutions and traditions. The writer Leopold Tyrmand (1920-85), whose proverbial colourful socks were supposed to oppose socialist reality and to enliven 'the grey hopelessness of socialism' in the I950s, was 'no doubt, a colourful bird, but mostly in Warsaw. In the less socialist Cracow, he did not stand out so much'. ${ }^{99}$

The politicization of colour in the I950s, when colours were meant to underpin the message of a novel, gave way to some freedom in the I960s, when the use of colours simply reflected reality without heavy symbolism. The writers of the I970s and I980s expressed their hopelessness by employing the colour traditionally connected in European culture with despair and gloom. Finally, post-I989 literature with its explosion of bright colours exposed the extent to which Communism has become associated with universal greyness in Polish literature and the degree to which colours have come to suggest the joys of freedom.

This article has explored colour only in Polish literature, but it would be useful to compare the place of colour with literature of other socialist countries to see whether social and political changes such as those which occurred in Budapest in 1956 or in Czechoslovakia in I968 had an impact on literature similar to that discernible in post-war Poland.

$9^{8}<$ http://www.zoneeuropa.tv/na/nao73 I 50.php>, [accessed October 3 I 2006].

99 Siedlecka, Wypominki, p. 269. 